\title{
Introduction: Several Aspects of Current Short Story Criticism - Influence, Gender and Genre
}

\author{
Yao $\mathbf{G u}^{1}$
}

Received: 23 December 2016/Accepted: 27 December 2016/Published online: 19 January 2017

(C) Fudan University 2017

"Influence," through Harold Bloom's efforts, becomes a keyword for poetic criticism. He argues in Anxiety of Influence that "poetic history...is held to be indistinguishable from poetic influence, since strong poets make that history by misreading one another"(Bloom 1997: 5-6) by examples like Oscar Wilde who knew he could not succeed in poetry for he had no means to escape consciously from his predecessor's influence. 'In Bloom's eyes, a strong poet is able to overcome his uneasiness in facing his literary forefathers, while a lesser one cannot. It should also be noted that Bloom mainly uses examples of male writers to support his claim of "anxiety," such as William Shakespeare and Christopher Marlow; so one is justified to ask whether the "anxiety of influence" is raised with an implication that this mental tendency of essentialism is peculiar to male writers in their pursuit of absolute originality. The present column "Several Aspects of Current Short Story Criticism: influence, gender and genre" may show otherwise.

If textual influence in Harold's sense is a temporal one, largely explored among male and white poets, then a short story writer's spiritual inheritance may come from the past, across the geographical border and between the genres. The column "Several Aspects of Current Short Story Criticism: influence, gender and genre" is designed to demonstrate how individual writer responds to various social and cultural and literary elements and what role their cultural identity or gender would play in the process of short story writing.

The four articles in this column came from the presentations at the 14th International Conference on the Short Story in English hosted by East China Normal

\footnotetext{
1 Bloom, Harold. The Anxiety of Influence: a Theory of Poetry. New York: Oxford University Press, 1973.

Yao Gu

guyao@fudan.edu.cn

1 Fudan Journal, Fudan University, 220 Handan Road, Shanghai 200433, China
} 
University at Shanghai in July 2016. The conference highlights the theme "Influence and Confluence in the Short Story: East and West"; and the very focus on "influence" suggests contemporary production of short stories benefit a lot from cross-cultural encounters and shows a sense of readiness to rethink intertextuality. The selected authors respectively come from Canada, mainland China and Taiwan; and two are male, while the other two female. These basic facts are listed to show a sense of geo-cultural-gender diversity of current short story criticism.

Bloomsbury Group was a casually connected circle of intellectuals who were active in London in the early twentieth century. Virginia Woolf was its most prominent figure; and her essays on literary theory and feminism and her novels like To the Lighthouse and Mrs. Dalloway still draw attention from both critics and common readers. The relation between Bloomsbury writers and the form of short story has often been overlooked. Ira Nadel's article "Bloomsbury Short Story" explores how some Bloomsbury writers developed the genre of short story through their active experimentation with techniques, syntax and imagery. A considerable part of it is devoted to the influence of Russian writers on Virginia Woolf and Katherine Mansfield. The new publication ambience also provides new cultural incentive for short story writing and its popular reception. Nadel concludes his analysis by briefly discussing Julian Barnes's short story as example of Bloomsbury's legacy as he absorbs "restraint, understatement and quiet revelation" in his writing.

Washington Irving's "Rip van Winkle" is a brilliant short story marked with humor, love for natural beauty and philosophical insight. Not quite often does one connect it with a Chinese folk tale of Wang Zhi in Western Jin Dynasty. In the article "Deism and Daoism in Washington Irving's 'Rip van Winkle'," Fang Kairui reveals the interesting relation between two stories and approaches the cultural liaison in the framework of influence study. With reference to historical documents, Fang seeks to reconstruct a cultural cosmos where Irving is able to know and understand China through trade, news reports, travel books and missionary translation of philosophical book Tao-Te-Ching. He argues that Irving's eastern imagination is transfigured into the writing of Rip van Winkle. The harmonious natural environment, Winkle's rustic nature and the ironic scene of Republican politics are depicted with Daoist sense of wisdom and deist reverence for the simple and the native.

The Canadian writer Alice Munro was awarded the Nobel Prize in Literature in 2013 when she was called "the master of contemporary short story." A considerable part of Munro's stories, set in her native town in Ontario, deals with the coming-ofage of women and their dilemma in marriage. In the article "Ways of Dealing with Adultery," Chu Chung-yi subjects three short stories dealing with woman adultery into close scrutiny. She first sketches out a brief history of adultery novels as a popular genre and stresses that such stories were often concluded with a sense of guilt and shame before the twentieth century. By reading Munro's three stories carefully, Chu argues that such tone of moral didactics is abandoned since the twentieth century and that Alice Munro treats those "affair" figures with sympathetic understanding. Accordingly from Georgia in "Differently" and Pauline in "The Children Stay" to Meriel in "What is Remembered," extramarital affairs 
are delineated like an opportunity for self-improvement or self-fulfillment for married women. In addition, Chu also reveals the intertextual relation between Munro's characters and their fictional predecessors, for instance "Eurydice" in "The Children Stay" and Turgenev's Fathers and Sons in "What is Remembered." These intertextual instances position Munro's short stories in the literary lineage of romantic story writing; and it also suggests that extramarital affairs make it possible for women to transcend the boredom of everyday life.

The English story writer Angela Carter is usually known for the mixed styles in her novels and short stories. The last article in the column "Carter's Feminist Revision of Fairy Tale" manifests the way how a woman writer resorts to short story to overcome the patriarchal influence of classic fairy tales. In this article, Sandra Gilbert and Susan Gubar are quoted to argue that classic fairy tales are malecentered to tell the stories of men such as "Little Red Riding Hood." In translating the classic folk tales, Wu Jie points out Angela Carter not only locates herself in the tradition of folk tales but also perceives the potential of these popular stories to be retold in the spirit of feminism. Carter presents the case of "The Company of Wolves" as her genre/gender experimentation. In this rewriting, female desire is given a positive image and women possess their autonomy rather than being purely the object of male gaze.

To sum up, the four articles collected here show that textual influence is more readily accommodated through short story genre and that women writers are more ready to accept the influence from their literary predecessors and more responsive in dealing with such influence. 